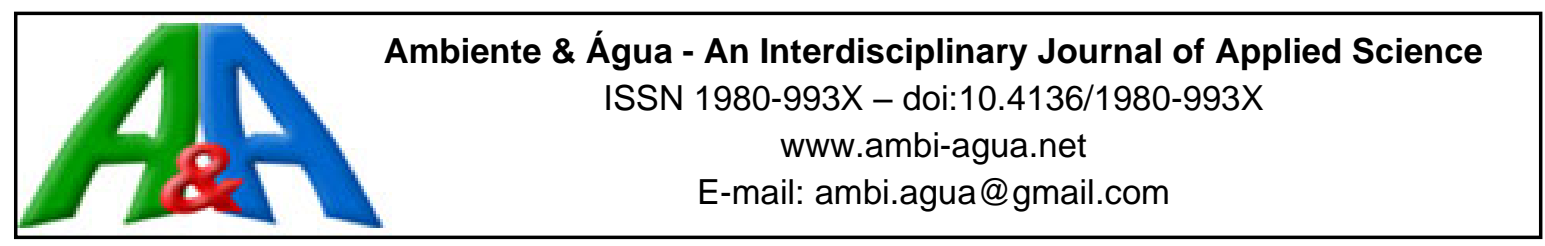

\title{
A hybrid approach associating flow network modeling with AHP- Entropy for simulating and ranking water-demand management alternatives
}

\author{
ARTICLES doi:10.4136/ambi-agua.2627
}

Received: 28 Jul. 2020; Accepted: 26 Feb. 2021

\author{
Matheus Duarte de Araújo*iD; Rui de Oliveira \\ Centro de Ciências e Tecnologia. Departamento de Engenharia Sanitária e Ambiental. Universidade Estadual da \\ Paraíba (UEPB), Rua Baraúnas, n 351, CEP: 58429-500, Campina Grande, PB, Brazil. \\ E-mail: ruideo@gmail.com \\ *Corresponding author. E-mail: matheusduarte887@gmail.com
}

\begin{abstract}
In view of the water crises historically experienced by Brazil's semi-arid region, it is necessary to search for methodological tools that allow us to propose efficient alternatives for managing water demand. In this regard, the present study developed and applied a hybrid approach of flow network modeling and the Analytic Hierarchy Process (AHP) combined with Shannon's entropy for simulating and prioritizing water demand management alternatives in the Epitácio Pessoa Reservoir in the Brazilian semiarid region. The approach initially performed simulations of the hydro system flow network to explore rational alternatives that evaluated the following criteria: meet the demands of human supply, meet the demands for irrigation, maintain the reservoir above the target volume, and reduce consumption. Subsequently, Shannon's entropy was used to assess the importance of the criteria and the multicriteria analysis of ranking of alternatives was built. Finally, a sensitivity analysis of the model was performed regarding the dependence on respective weights of the criteria. The results made enabled evaluation of the hydro system's water security, highlighting insufficient supply by the single measure of water management transposition of the São Francisco River, and based on the hierarchy of alternatives, suggesting actions to improve the sustainability of water use, such as reuse of water, reduction of losses in supply systems and increasing irrigation efficiency. The proposed hybrid approach permitted the synthesis of the simulation's results, which may simplify and support the decision-making process in water-demand management.
\end{abstract}

Keywords: AHP-Entropy, consumption reduction, flow network, water demand management.

\section{Uma abordagem híbrida associando modelagem de rede de fluxo a AHP-Entropia para simulação e hierarquização de alternativas de gerenciamento da demanda de água}

\section{RESUMO}

Diante das crises hídricas historicamente vivenciadas pelo semiárido do Brasil, é necessário buscar ferramentas metodológicas que possibilitem propor alternativas eficientes de gerenciamento da demanda de água. Nesse contexto, o presente estudo desenvolveu e aplicou uma abordagem híbrida de modelagem de rede de fluxo e Analytic Hierarchy Process (AHP) 
combinada à entropia de Shannon, para simular e hierarquizar alternativas de gerenciamento da demanda de água do reservatório Epitácio Pessoa, no semiárido brasileiro. A abordagem inicialmente realizou simulações da rede de fluxo do hidrossistema admitindo alternativas voltadas à sustentabilidade, avaliando os critérios: atendimento às demandas de abastecimento humano, atendimento à demanda de irrigação, manutenção do reservatório acima do volume meta e redução de consumo. Posteriormente, a entropia de Shannon foi utilizada para aferir a importância dos critérios, e foi desenvolvida a análise multicritério de hierarquização das alternativas. Por fim, foi realizada uma análise de sensibilidade do modelo quanto a dependência dos pesos dos critérios. Os resultados possibilitaram avaliar a segurança hídrica do hidrossistema, apontando insuficiência do abastecimento pela medida única de gerenciamento da transposição do rio São Francisco, permitindo sugerir, baseado na hierarquização de alternativas, medidas voltadas à sustentabilidade do uso da água que adotem mecanismos poupadores, reuso, reduzam as perdas e aumentem a eficiência na irrigação. A abordagem híbrida proposta permitiu sintetizar os resultados da simulação, o que pode apoiar e simplificar o processo de tomada de decisão no gerenciamento da demanda de água.

Palavras-chave: AHP-Entropia, gerenciamento da demanda de água, rede de fluxo, redução de consumo.

\section{INTRODUCTION}

Meeting the extensive water demands is a challenge to Brazil's semiarid region mainly due to population growth, economic development, the increase in the rate of urbanization in recent years and the diversity of weather conditions (Araújo et al., 2019).

Barros et al. (2016) state that semiarid regions, such as the one in which the Epitácio Pessoa Reservoir is located, in Paraíba, present precipitation with significant spatial and temporal irregularity in addition to a high evaporation rate. These factors lead to uncertainty in meeting human, industrial and agricultural water needs.

Active and efficient management is a prerequisite for the efficient and correct use of this resource. In addition to the challenge of meeting the resource demands, irrational and unrestrained use of water occurs in large cities (Bailone and Roça, 2017). Demand management in a basin aims to increase availability, achieve social justice, and protect ecosystems in the environment. It therefore requires identifying the best methods of reservation, allocation and use of the resource. One option to study the water allocation aspects of a reservoir is to build methods that support decision-making in choosing the best management model, which has to have greater water transfer capacity and optimize the relation between supply and demand (Bakhshianlamouki et al., 2020).

Simulation and optimization models are technological tools with mathematical formulation and can be used by managers responsible for reservoirs to aid in water-demand management (Abokifa et al., 2016). Some of these decision-making assistive models are flow network models. The modeling is done through a mass balance by an algorithm and is commonly used to solve water allocation problems in complex basins (Boulos, 2017). The various studies that use flow network models as support tools present methodologies that vary between the use of isolated and hybrid models, which are combined methods or systems.

Isolated flow network modeling was used by Silva et al. (2019), who assessed vulnerabilities in meeting the water demand in Fortaleza and analyzed the emptying regime of the Castanhão Reservoir. Based on the methodology, the authors proposed variations in the region's supply system and indicated the use of economical sanitary appliances and financial mechanisms.

In Iran, Shourian et al. (2017), addressing an imbalance in the temporal and spatial 
distribution of water, used flow network modeling to develop a proposal for transposing water between a high-availability basin to a nearby high-consumption basin.

In a hybrid approach, flow network modeling was associated with, among others, the FPEIR matrix (Araújo et al., 2019) for environmental diagnosis, with the construction of water management scenarios to evaluate water transfer capacities between basins (Shourian et al., 2017) and with multicriteria analysis for definitions of environmental preservation areas (Santos et al., 2019) and vulnerability status of water resource systems (Shabbir and Ahmad, 2016; Alamanos et al., 2018).

Among the multicriteria analysis methods, which can be associated with flow network models, according to Saaty (1991) the AHP is the most frequently used in studies of water and sewage (Tscheikner-Gratl et al., 2017). The method was chosen for this study because it has broad applicability, robustness, and flexibility (Vieira et al., 2017), and it is usually used to evaluate and support decisions that have multiple goals.

The AHP is based on pairwise comparisons, both to estimate weights of the criteria and to compare alternatives regarding the decision criteria, which is a subjective analysis based on the decision maker's preferences (Saaty, 1991). However, as per Mulliner et al. (2016), if the criteria weight values cannot be obtained directly, then an objective method based on pairwise comparisons should be employed, such as Shannon's entropy.

Shannon's entropy, derived from information theory, is a mathematical method to define the uncertainties of numerical data, taking into account all types of information, thus quantifying information regarding flows in data (Shannon, 1951).

Ding et al. (2018) combined AHP-Entropy approach with GIS for construction caste landfill selection in China, Feizi et al. (2017) combined AHP-Entropy and GIS to develop a mineral potential map in Iran, and Roodposhti et al. (2016) combined a multicriteria method with Shannon Entropy to develop a hybrid GIS-based landslide-susceptibility map in Iran.

In this context, the present study uses a hybrid approach by associating methodologies with flow network modeling and entropy-multicriteria methods as a decision-support tool in complex water systems. The difference in this approach is the unprecedented combination of the AHP-Entropy method with flow-network modeling. In addition to analyzing the vulnerability of a water system, it can simulate management alternatives and classify them in hierarchical order to simplify the decision-making process. Finally, this study aims to develop and apply a hybrid approach of AHP-Entropy with flow network modeling to simulate the Epitácio Pessoa hydro system based on water-demand management alternatives, identifying and ranking the best ones.

\section{MATERIALS AND METHODS}

The proposed methodological steps of the hybrid approach involve: i) definition and characterization of the study area; ii) description and simulation of water allocation in the hydro system by water demand management alternatives; iii) hierarchy definition of alternatives through the AHP-Entropy method; and iv) sensitivity analysis of the ranking results, considering criteria priorities.

\subsection{Study area}

To apply this hybrid approach associating flow network modeling with AHP-Entropy, the first step is to define the hydro application system so that this approach can be practical for any reservoir water system. The present study applied the hybrid approach at Epitácio Pessoa Reservoir, located in the Paraíba River hydrographic basin. The basin comprises $35.7 \%$ of the territory of Paraíba and drains an area of $20,127 \mathrm{~km}^{2}$, which includes the second-largest city in the state, Campina Grande, and 84 more municipalities. The reservoir is located in the Upper Course of the river, a hydrographic region characterized as one of Brazil's lowest rainfall 
averages. The total annual rainfall is $600 \mathrm{~mm}$ and is concentrated in February, March, April and May.

The reservoir is characterized by the challenge of coping with scarcity in a context of supplying about 700 thousand inhabitants, and supplying industrial, educational and economic centers. The study area is historically characterized by water crises, as in the most recent interval of 2012-2017, in which there were 4 phases of rationing from the suspension of water supply for irrigation to the interruption of supply for up to 112 hours to some neighborhoods of Campina Grande.

\subsection{Description and simulation of water allocation in the hydro system based on demand management alternatives, using the flow network model}

The second step is the hydro system simulations of water demand management alternatives, using a flow network model. This stage can be performed through software that operates flow network models, such as, among others, IRIS, IRAS, AQUATOOL, RIVERWARE MIKE BASIN, MODSIM DDS, and AcquaNet (Vieira and Curi, 2016).

The input information required for the hydro system flow network modeling is the quotaarea-volume curve, initial volume in the simulation time, granted demands, priorities to meet demands, evapotranspiration flows, and affluent flows. The output data, among others, establish the frequency that the hydro system operated below the required demand, the average required demand and the average flow rate provided, the frequency with which it was poured, and the time of operation of the reservoir below pre-defined volumes.

AcquaNet flow network software, which is a modification of MODSIM, was chosen to simulate the allocation of water and analyze the fulfillment of demands due to the ease of operation and the possibility of agricultural planning; these aspects differ from other simulation and optimization models.

This study simulated the allocation of Epitácio Pessoa for the 2004-2017 interval. The input data were obtained from the DNOCS reports for the reservoir's physical data, and the collection of climatological and concession data in the HidroWeb system of the National Water Agency. The optimization was performed monthly and sequentially, not guaranteeing the optimum overall time ahead.

Figure 1 shows the flow network of the Epitácio Pessoa Reservoir responsible for supplying 24 municipalities. The model represents the hydro system of volume (reservoir), passage (confluences, points of entry, flow, and points of demands), and arcs or links (channels, supply channels, and natural rivers). The present municipalities' demands are distributed in human supply (HUM), irrigation (IRRIG) and livestock (LIV), with no industrial demands in the national grant report for the reservoir.

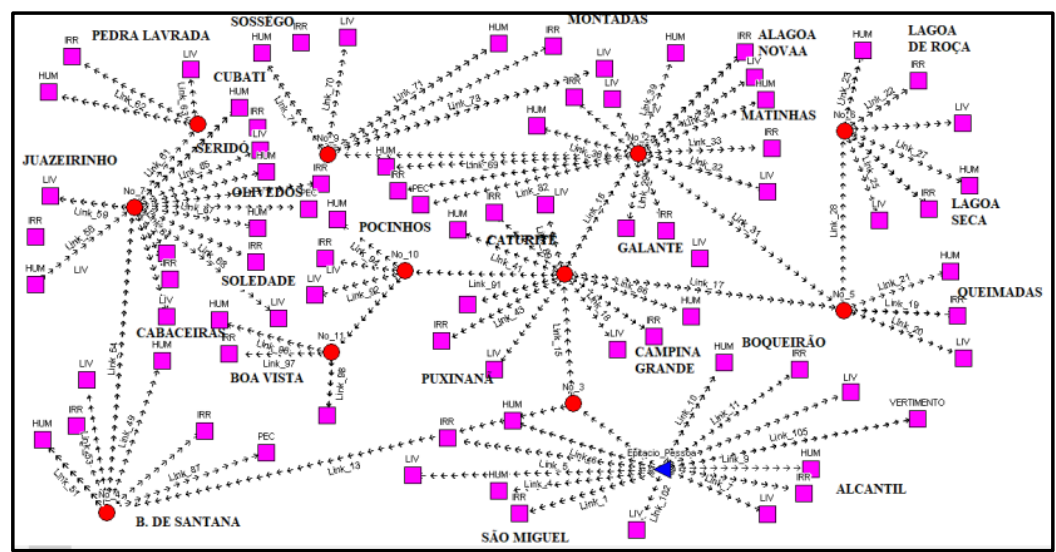

Figure 1. Flow network of the Epitácio Pessoa hydro system in the Upper Course of the Paraíba River region. 
To complete this step with all the input data required by the software, it is necessary to simulate water-demand management alternatives in the flow network model. These alternatives must be identified through the measures already implemented in the hydrographic basin, that may interfere with the water balance of the system, and from technical literature on demand management. Therefore, to computationally simulate and evaluate alternatives, the hydro system is reproduced with modified input data referring to possible demand reductions and variations in the quantities and inflow regimes to the reservoir.

According to the methodological approaches of Barros et al. (2016), Almeida and Curi (2016), and Sousa (2017), from technical literature and possible structural works, it is pointed out that for effective water management in regions of scarcity, as in this case study, it is necessary to apply management alternatives based on considerations of rationality, modernization, and sustainability of water management.

Table 1 shows alternatives applied for this case study : technological alternatives (A1 to A5), that can be replicated for any hydro system, based on the literature (Sousa, 2017); associated structural alternatives (A6 and A7) referring to the case study; and their combinations (A8 to A12) were simulated in comparison to a reference scenario (A0).

After simulating the flow network for a perspective absent of alternatives (A0) and management alternatives (A1 to A12), a multicriteria method associated with an objective weighting method is used, as a decision support tool, to classify the simulated alternatives.

Table 1. Waterdemand management alternatives simulated in the flow network.

\section{Alternative description}

\begin{tabular}{|c|c|c|}
\hline A0 & Reference Scenario & $\begin{array}{l}\text { The reference scenario does not allow management measures. Therefore, } \\
\text { it considers the water consumption in homes by hydraulic devices without } \\
\text { sparing devices, without sustainable projects for reuse, and simulated from } \\
\text { the inflow through precipitation. }\end{array}$ \\
\hline A1 & Saving equipment & $\begin{array}{l}\text { Replacement of common equipment by saving equipment, which are: } \\
\text { showers with flow restrictors, sanitary basins with double activation, sink } \\
\text { faucets with aerators, and lavatory faucets with aerators. }\end{array}$ \\
\hline $\mathrm{A} 2$ & Rainwater harvesting & $\begin{array}{l}\text { Implementation of a rainwater catchment system composed of gutter, pipe, } \\
\text { first water diversion device, lower reservoir, pumping, upper reservoir, and } \\
\text { home distribution. }\end{array}$ \\
\hline A3 & Residential reuse & $\begin{array}{l}\text { Use of a graywater reuse system with treatment for recirculating } \\
\text { wastewater from showers and washing machines to the sanitary basin. }\end{array}$ \\
\hline A4 & $\begin{array}{l}\text { Equipment }+ \text { Rainwater } \\
\text { harvesting }\end{array}$ & This alternative combines the alternatives (A1) and (A2). \\
\hline A5 & Equipment + reuse & This alternative combines the alternatives (A1) and (A3). \\
\hline A6 & $\begin{array}{l}\text { Water transposition } \\
\text { every month }\end{array}$ & $\begin{array}{l}\text { This alternative considers a water supply of } 1.52 \mathrm{~m}^{3} \mathrm{~s}^{-1} \text { (ANA, 2017) to the } \\
\text { reservoir every month, coming from the East Axis of the São Francisco } \\
\text { River Transposition Program. It should be noted that the frequent context } \\
\text { of scarcity in the São Francisco River Basin would have to be considered } \\
\text { for the transfer of water to basins in the semiarid (Rêgo et al., 2017). }\end{array}$ \\
\hline A7 & $\begin{array}{l}\text { Water transposition in the } \\
\text { period of lesser influx }\end{array}$ & $\begin{array}{l}\text { Considering the rainy season from February to May (Andrade et al., 2019); } \\
\text { the minimum average rainfall of } 20 \mathrm{~mm} \text { in January, June, and July; water } \\
\text { scarcity in the São Francisco River Basin; and the high costs of operating } \\
\text { the system, the alternative considers the water supply of } 1.52 \mathrm{~m}^{3} \mathrm{~s}^{-1} \text { in the } \\
\text { months of August to December, as those of lowest inflow to the reservoir. }\end{array}$ \\
\hline
\end{tabular}

Continue...

Rev. Ambient. Água vol. 16 n. 2, e2627 - Taubaté 2021 


\begin{tabular}{|c|c|c|}
\hline \multicolumn{3}{|c|}{ Continued... } \\
\hline A8 & $\begin{array}{l}\text { Equipment }+ \text { residential } \\
\text { reuse }+ \text { water } \\
\text { transposition in the lesser } \\
\quad \text { influx }\end{array}$ & $\begin{array}{l}\text { This alternative combines the alternatives that use saving equipment (A1), } \\
\text { a residential reuse system (A3), and the alternatives that use the water } \\
\text { supply of the transposition of the São Francisco River in the months of less } \\
\text { affluence (A7). }\end{array}$ \\
\hline A9 & $\begin{array}{l}\text { Equipment + } \\
\text { ETA reuse }\end{array}$ & $\begin{array}{l}\text { This alternative combines the alternatives that use saving equipment (A1) } \\
\text { with the use of } 20 \% \text { of the treated effluent (filter washing water + sludge) } \\
\text { from the ETAs of the Epitácio Pessoa Reservoir for irrigation. }\end{array}$ \\
\hline A10 & $\begin{array}{l}\text { Equipment }+ \\
\text { Loss reduction }\end{array}$ & $\begin{array}{l}\text { This alternative combines the alternatives that use saving equipment (A1) } \\
\text { with a } 20 \% \text { reduction in losses in the distribution system by the water and } \\
\text { sewage company. }\end{array}$ \\
\hline A11 & $\begin{array}{l}\text { Equipment + Irrigation } \\
\text { efficiency }\end{array}$ & $\begin{array}{l}\text { According to CEMIG, the incorrect management of water in irrigation } \\
\text { causes a waste of } 20 \% \text { of water and } 25 \% \text { of electricity. This alternative } \\
\text { combines the alternatives that use saving equipment (A1) with efficient } \\
\text { management measures that increase water-use efficiency from } 75 \% \text { to } \\
90 \% \text {. }\end{array}$ \\
\hline A12 & $\begin{array}{l}\text { Water transposition in the } \\
\text { lesser influx }+ \text { irrigation } \\
\text { efficiency }+ \text { equipment }+ \\
\text { reuse }+ \text { loss reduction }\end{array}$ & $\begin{array}{l}\text { This alternative combines the main water demand management } \\
\text { alternatives in the study. The alternatives that use saving equipment (A1), } \\
\text { graywater reuse (A3) to transfer water to the lowest inflow months (A7), } \\
\text { reducing losses in the supply system (A10) and increasing water supply } \\
\text { irrigation efficiency (A11). }\end{array}$ \\
\hline
\end{tabular}

\subsection{Hierarchy definition of alternatives through the AHP-Entropy method}

The third step is the hierarchy definition of alternatives through the AHP-Entropy method. The AHP-Entropy is used as a decision support tool to classify the simulated alternatives in a ranking. The flow network's performance results are used as the basis of AHP-Entropy, forming the data structure of the numerical matrix.

The data and criteria required from the multicriteria analysis must be selected by hydro system performance results of simulated alternatives in the flow network model. In this study case, years with reasonable water scarcity were chosen: therefore, meeting the human supplydemand $\left(\mathrm{C}_{1}\right)$; meeting the irrigation demand $\left(\mathrm{C}_{2}\right)$; the percentage of the reservoir volume above the target volume $\left(\mathrm{C}_{3}\right)$, which is a percentage of the volume that must be kept in the reservoir from one month to another; and reduced consumption $\left(\mathrm{C}_{4}\right)$.

In this approach, as in Mulliner et al. (2016), Yang et al. (2019), and Leal (2020), the criteria weights are objectively determined by Shannon's entropy and not by peer comparison of AHP. Only the final stages of the AHP are required, which is the processing of normalized numerical values.

The calculation of Shannon's entropy weights, according to Lotfi and Fallahnejad (2010), is presented below:

In a multicriteria problem assuming alternatives $m\left(A_{1}, A_{2}, \ldots, A_{m}\right)$ and $n$ criteria $\left(C_{1}, C_{2}\right.$, $\ldots, C_{m}$ ), the initial decision matrix is:

$\left[\begin{array}{cccc}a_{11} & a_{11} & \ldots & a_{1 n} \\ a_{21} & a_{22} & \ldots & a_{2 n} \\ \vdots & \vdots & \ddots & \vdots \\ a_{m 1} & a_{m 2} & \ldots & a_{m n}\end{array}\right]=\left[a_{i j}\right]_{m \times n}$

Where its components $a_{i j}$ denote $i$ th alternative of $j$ th criterion.

Stage 1: Normalize the decision matrix (Equation 1) 
$r_{i j}=\frac{a_{i j}}{\sum_{i=1}^{m} a_{i j}}, i=1,2, \ldots, m$

Stage 2: Compute entropy (Equation 2)

$e_{j}=-K \sum_{i=1}^{m} r_{i j} \ln r_{i j}, j=1,2, \ldots, n$

Where: $K=\frac{1}{\ln m}$

Stage 3: Calculate the weights of each criterion (Equation 3)

$w_{i j}=\frac{1-e_{j}}{\sum_{i=1}^{n}\left(1-e_{j}\right)}, j=1,2, \ldots, n$.

The final stage of the AHP (Equation 4), according to Mulliner et al. (2016), deals with the construction of a matrix $M x N$ (where $M$ is the number of alternatives and $N$ is the number of criteria), which is computed using the relative importance of the alternatives in terms of each criterion. Alternatives are classified using the following additive formula:

$$
A_{A H P}^{*}=\max \sum_{j=1}^{N} a_{i j} w_{j} \text { for } i=1,2,3 \ldots, M
$$

Where: $\mathrm{A}_{A H P}^{*}$ is the score of the optimal alternative; $a_{i j}$, in the $M x N$, represents the actual value of the $i t h$ alternative in terms of the $j$ th criterion; $w_{j}$ is the weight of importance of the $j t h$ criterion and $N$ is the number of decision criteria.

\subsection{Sensitivity analysis}

As the fourth step of this hybrid approach, developing a sensitivity analysis is a crucial phase to analyze the impact of criteria weights on ranking the alternatives. Therefore, in this subsection, similarly to the applications of MCDM's sensitivity analyses by Štreimikiene et al. (2016), Al Garni et al. (2016), and Boran (2018), a classification sensitivity of water demand management alternatives (if any) was obtained in five scenario criteria preferences: Scenario 1: Equal weight $\left(\mathrm{Sc}_{1}\right)$; Scenario 2 Human supply $\left(\mathrm{Sc}_{2}\right)$, Scenario 3: Irrigation $\left(\mathrm{S}_{\mathrm{C} 3}\right)$, Scenario 4: Maintenance of Reservoir $\left(\mathrm{S}_{\mathrm{C} 4}\right)$ and Scenario 5: Reduction of consumption $\left(\mathrm{S}_{\mathrm{C} 5}\right)$.

The scenarios are based on altering the weight, and consequently prioritizing the water demand management by the main criteria (Table 2). In Scenario 1, every dimension is treated as equally important. In the following four scenarios, for example, in $\mathrm{Sc}_{2}$, the greater weight is for $\mathrm{C}_{1}$, equally dividing the remaining weight for the other criteria. And similarly, $\mathrm{S}_{\mathrm{C} 2}, \mathrm{~S}_{\mathrm{C} 3}, \mathrm{~S}_{\mathrm{C} 4}$, and $\mathrm{S}_{\mathrm{C} 5}$. This type of sensitivity analysis makes it possible to look into each criterion's effect on the alternative choice. The related ranks of water demand management alternatives were obtained by using the AHP method.

Table 2. Criteria weights under different scenarios.

\begin{tabular}{ccccccc}
\hline Criteria & $\begin{array}{c}\text { Scenario 1: } \\
\text { Equal weight }\end{array}$ & $\begin{array}{c}\text { Scenario 2: } \\
\text { Human supply }\end{array}$ & $\begin{array}{c}\text { Scenario 3: } \\
\text { Irrigation }\end{array}$ & $\begin{array}{c}\text { Scenario 4: } \\
\text { Maintenance } \\
\text { of Reservoir }\end{array}$ & $\begin{array}{c}\text { Scenario 5: } \\
\text { Reduction of } \\
\text { consumption }\end{array}$ \\
\hline $\mathrm{C}_{1}$ & $\begin{array}{c}\text { Meeting the human } \\
\text { supply demand }\end{array}$ & 0.25 & 0.5 & 0.167 & 0.167 & 0.167 \\
\hline $\mathrm{C}_{2}$ & $\begin{array}{c}\text { Meeting the } \\
\text { irrigation demand }\end{array}$ & 0.25 & 0.167 & 0.5 & 0.167 & 0.167 \\
\hline $\mathrm{C}_{3} \quad \begin{array}{c}\text { Reservoir volume } \\
\text { above the target volume }\end{array}$ & 0.25 & 0.167 & 0.167 & 0.5 & 0.167 \\
\hline $\mathrm{C}_{4}$ & Reduced consumption & 0.25 & 0.167 & 0.167 & 0.167 & 0.5 \\
\hline
\end{tabular}




\section{RESULTS AND DISCUSSION}

The results are presented and discussed in two sections: i) flow network simulation for demand management alternatives; ii) ranking of criteria and alternatives according to AHPEntropy, and sensitivity analysis of alternatives ranking due to variation of criteria weights.

\subsection{Flow network simulation for water demand management alternatives}

The Epitácio Pessoa hydro system simulations, shown in Figure 2, represent the capacity of the system to meet the main demands based on the proposed management alternatives. Table 3 shows the demand percentages, absolute values of consumption reduction, external water supply, frequency of the reservoir volume operating below the target volume, and the supply failures according to the alternatives evaluated.

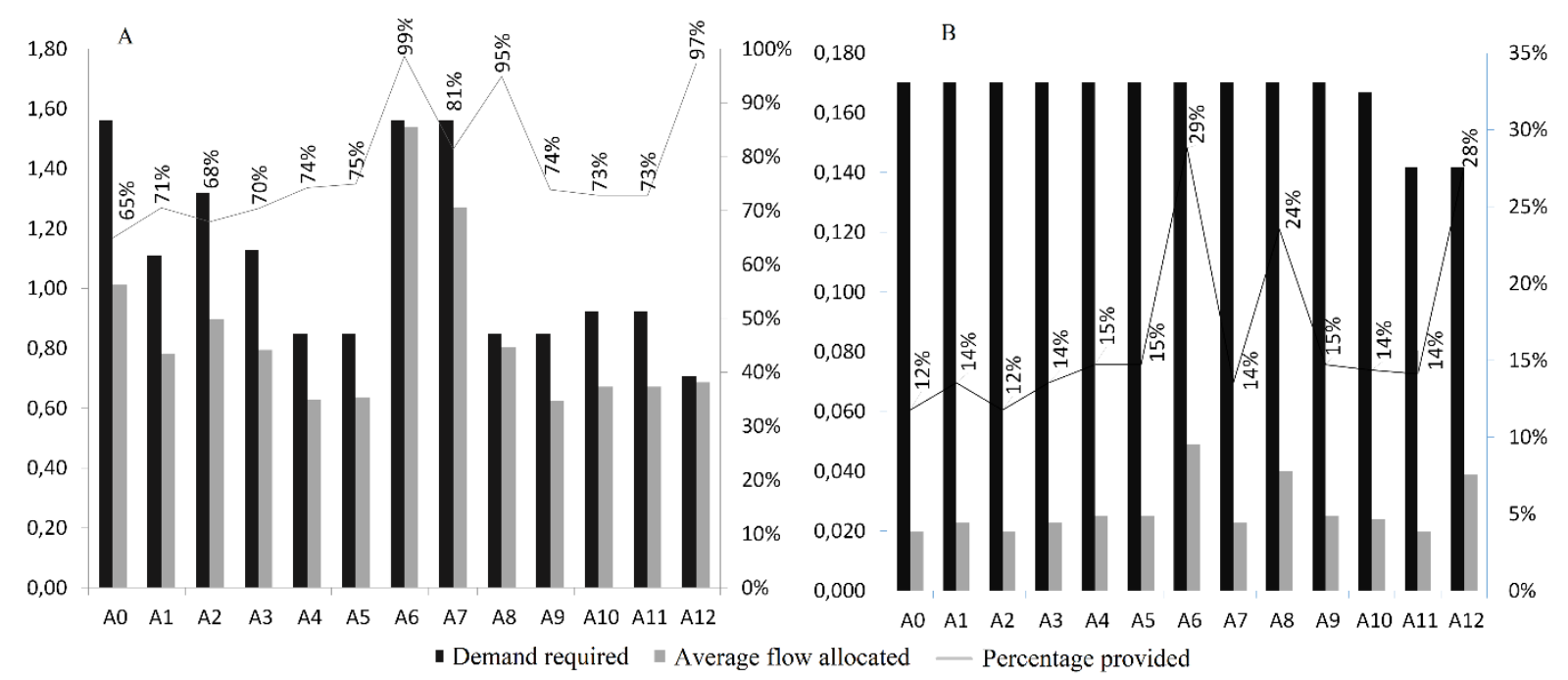

Figure 2. A) human supply. B) Irrigation: flows demanded by alternative management, average flows allocated and the percentage of meeting the required demand.

Table 3. Characteristics and results of meeting demands for alternative demand management.

\begin{tabular}{|c|c|c|c|c|c|c|}
\hline \multirow{2}{*}{$\begin{array}{l}\text { Management } \\
\text { alternatives of } \\
\text { demand }\end{array}$} & \multirow{2}{*}{$\begin{array}{c}\text { Demand } \\
\text { reduction } \\
\text { percentages }(\%)\end{array}$} & \multirow{2}{*}{$\begin{array}{c}\text { Total } \\
\text { consumption } \\
\text { reduction }\left(\mathrm{m}^{3} \mathrm{~s}^{-1}\right)\end{array}$} & \multirow{2}{*}{$\begin{array}{c}\text { External } \\
\text { water supply } \\
\left(\mathrm{m}^{3} \mathrm{~s}^{-1}\right)\end{array}$} & \multirow{2}{*}{$\begin{array}{l}\text { Frequency below } \\
\text { target volume } \\
(\%)\end{array}$} & \multicolumn{2}{|c|}{ Failure to meet demand } \\
\hline & & & & & $\underset{(\%)}{\text { Human }}$ & $\begin{array}{c}\text { Irrigation } \\
(\%)\end{array}$ \\
\hline $\mathrm{A} 0$ & - & - & - & 88.1 & 36.3 & 88.1 \\
\hline A1 & 20.7 & 0.45 & - & 74.3 & 30.9 & 86.9 \\
\hline A2 & 11.2 & 0.24 & - & 76.5 & 33.9 & 88.1 \\
\hline A3 & 19.7 & 0.43 & - & 74.8 & 30.9 & 86.9 \\
\hline A4 & 31.9 & 0.71 & - & 69.8 & 28.6 & 85.1 \\
\hline A5 & 32.6 & 0.72 & - & 69.7 & 28.0 & 85.1 \\
\hline A6 & - & - & 1.52 & 47.8 & 5.4 & 72.0 \\
\hline A7 & - & - & $1.52^{1}$ & 64.6 & 30.9 & 80.3 \\
\hline A8 & 32.6 & 0.71 & $1.52^{1}$ & 50.7 & 7.7 & 76.8 \\
\hline A9 & 32.8 & 0.71 & $0.0033^{2}$ & 69.8 & 28,0 & 85.1 \\
\hline A10 & 29.2 & 0.64 & - & 73.8 & 29.2 & 85.7 \\
\hline A11 & 35.6 & 0.67 & - & 72.7 & 29.2 & 85.7 \\
\hline A12 & 42.7 & 0.88 & $1.52^{1}$ & 46.8 & 3.6 & 73.2 \\
\hline
\end{tabular}

Note ${ }^{1}$ : water supply of $1.52 \mathrm{~m}^{3} \mathrm{~s}^{-1}$ coming from the transposition only in the months of lesser influx. Note $^{2}$ : water supply of $20 \%$ of the treated effluent (filter washing water + sludge) from the ETAs of the Epitácio Pessoa Reservoir.

Regarding the simulation of the reference scenario (A0), it was observed that the absent system of management measures presents a frequency of meeting human demands (combined 
urban and rural) of only $65 \%$ of the simulated period. The severity of this failure is even more accentuated in the system's capacity to meet irrigation demands, which results in damage to the development of the economic region.

The individualized alternatives (A1; A2; A3) that admit concepts of sustainability in residential hydraulic networks present reductions of consumption that increase human supply capacity to the percentage of $71 \%$ in the simulated period. Among the alternatives, it should be noted that the gray water reuse project (A3) is more expensive and more operationally complex to implement than the saving mechanism (A1) and rainwater catchment (A2) systems.

The flow network simulations from the combined alternatives (A4; A5) showed similar percentages of capacity to attend the human supply, respectively, $74 \%$ and $75 \%$, and reduced the time of the reservoir below the target volume, generating less risk of operation of the reservoir at critical levels and lower water consumption. The return-on-investment time is evident as a difference between the combined alternatives, which, according to Sousa (2017), is six years and three months for the system adopted by (A4) and nine years and seven months for the system (A5).

The alternative (A6) that uses the water supply of the São Francisco River's transposition is the current management alternative in the basin. The alternative has the best percentage of meeting the demands with human supply met at $99 \%$ during the simulated period. It is important to note that, according to Rêgo et al. (2017), a transposition is a radical management alternative adopted in the semiarid region. The alternative was adopted after the critical state in the supply of the municipalities supplied by the Epitácio Pessoa Reservoir, which also impacts water insecurity in the São Francisco River's hydrographic region. However, the alternative should have been adopted only after all the rational, modern and sustainable solutions for water management demand, including those of an economic and financial nature, had been adopted.

The alternative (A7), which proposes the use of water resources of $1.52 \mathrm{~m}^{3} \mathrm{~s}^{-1}$ during the less affluent months, would mitigate the intensification of conflicts in the São Francisco River Basin, in the simulated period reduced the frequency of the reservoir below the target volume to $64.6 \%$. However, it proved to be insufficient in generating water security for the region, as it presents $30.9 \%$ of failures in human supply.

The combinations of alternatives (A8; A9; A10; A11) represent shared responsibility among users. This sharing was demonstrated in the alternative (A10), between rationality in the end user's consumption and the reduction of losses by the company granted by the supply system. In this configuration, the $20 \%$ reduction in losses, combined with the use of energysaving equipment, obtained a lower percentage of failures in meeting demand (29.2\%) than the alternative (A7) that uses the water supply of the transposition in the months less affluent $(30.9 \%)$.

The alternative (A12) showed the most significant consumption reduction, the shortest time below the target volume, and the average allocated flow of $97 \%$ of the flow demanded human supply. The alternatives (A12; A6), which differ in the period of use of the water supply of the Transposition of the São Francisco River - East Axis and the adoption of sustainable measures, presented different percentages of failures in the simulated period. The reduction in consumption proposed in (A12) decreased the susceptibility to failures in meeting human demand, indicated in its $3.6 \%$, compared to $5.4 \%$ of the alternative (A6). Such results demonstrate that obtaining a more significant water volume through transposition does not guarantee water reliability to the system, requiring efficient management measures and reducing consumption.

\subsection{Hierarchization of criteria and alternatives according to AHP-Entropy and sensitivity analysis}

Based on the data of flow network modeling results in Table 3, Shannon's entropy was used to calculate the relative importance, as an objective approach, of considered criteria in 
ranking the water demand management alternatives. Table 4 shows that the most important consideration is for criterion $\mathrm{C}_{1}$, followed, in hierarchical order, by $\mathrm{C}_{3}, \mathrm{C}_{2}$, and $\mathrm{C}_{4}$.

Table 4. Shannon's entropy weight.

\begin{tabular}{llcc}
\hline & Criteria & Objective Weight & Ranking \\
\hline $\mathrm{C}_{1}$ & Meeting the human supply demand & 0.273 & 1 \\
$\mathrm{C}_{2}$ & Meeting the irrigation demand & 0.260 & 3 \\
$\mathrm{C}_{3}$ & Reservoir volume above the target volume & 0.270 & 2 \\
$\mathrm{C}_{4}$ & Reduced consumption & 0.201 & 4 \\
\hline
\end{tabular}

Since criteria and their relative weights, multicriteria simplified AHP was applied to the flow network data, the method provides a decision vector for the alternatives considered so that the higher, the better the alternative is classified. Figure 3 presents the decision vector results in AHP-Entropy, by alternative demand management considered, according to the objective weights.

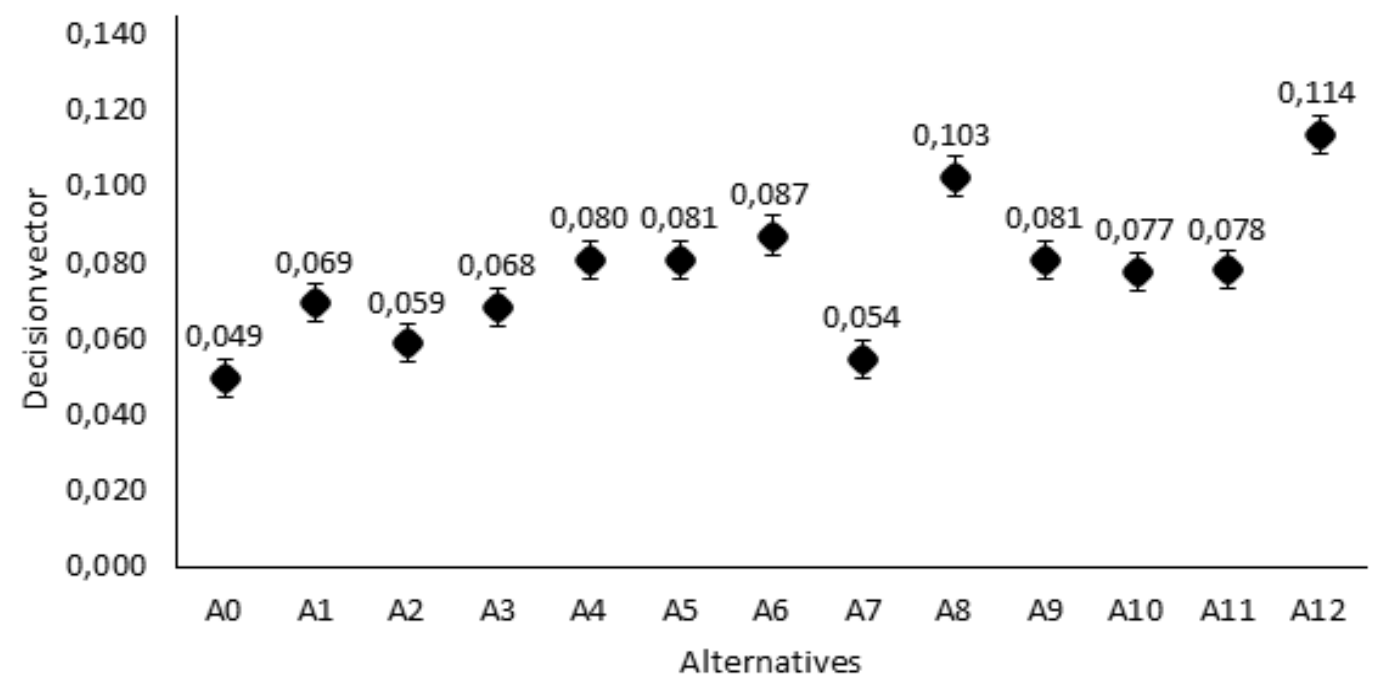

Figure 3. Decision vector of the AHP-Entropy by alternative demand management.

According to the results of AHP-Entropy, it is identified that the choice of the demand management alternative presented a hierarchy of A12 > A8 > A6 > A9 > A5 > A4 > A11>A10 $>\mathrm{A} 1>\mathrm{A} 3>\mathrm{A} 2>\mathrm{A} 7>\mathrm{A} 0$ for the analyzed criteria.

Since the weight of the criteria significantly affects the classification, the weight value change must be evaluated. The ranking is analyzed in different scenarios (Table 5), considering the criterion as preferential in each one.

Table 5. The ranks in terms of considered scenarios.

\begin{tabular}{|c|c|c|c|c|c|c|c|c|c|c|c|c|c|c|}
\hline & \multirow{2}{*}{ Scenario } & \multicolumn{13}{|c|}{ Ranking } \\
\hline & & 1 & 2 & 3 & 4 & 5 & 6 & 7 & 8 & 9 & 10 & 11 & 12 & 13 \\
\hline $\mathrm{Sc}_{1}$ & Equal weight & A12 & A8 & A6 & A9 & A5 & A4 & A11 & A10 & A1 & A3 & A2 & A7 & A0 \\
\hline $\mathrm{Sc}_{2}$ & Human supply & A12 & A8 & A6 & A9 & A5 & A4 & A11 & A10 & A1 & A3 & A2 & A7 & A0 \\
\hline $\mathrm{Sc}_{3}$ & Irrigation & A12 & A8 & A6 & A9 & A5 & A4 & A11 & A10 & A1 & A3 & A2 & A7 & A0 \\
\hline $\mathrm{Sc}_{4}$ & Maintenance of Reservoir & A12 & A8 & A6 & A9 & A5 & A4 & A11 & A10 & A1 & A3 & A2 & A7 & A0 \\
\hline $\mathrm{Sc}_{5}$ & Reduction of consumption & A12 & A8 & A9 & A5 & A4 & A11 & A10 & A1 & A3 & A6 & $\mathrm{A} 2$ & A7 & A0 \\
\hline
\end{tabular}


According to the results, for scenarios $\mathrm{Sc}_{1}, \mathrm{Sc}_{2}, \mathrm{Sc}_{3}, \mathrm{Sc}_{4}$ the choice of the demand management alternatives for the analyzed criteria is the same hierarchical order as in AHPEntropy method. In contrast, scenario $\mathrm{Sc}_{5}$ presented a different hierarchy.

Among the alternatives, the one that considers the water supply only in the months with the lowest inflow (A7) is the penultimate placed among all the simulations, and the last, if only the measures that consider some management measure are taken. This is because there is no reduction in consumption for the hydro system, although technically, it presents similar percentages of service than the alternatives that adopt sustainable projects for homes (A1, A2, A3).

It is verified in the scenario $\mathrm{Sc}_{5}$ that the alternatives that consider combined measures of sustainable residential projects (A1, A3, A4, A5), use of saving equipment combined with loss reduction (A10), and the use of the same equipment combined with an increase in irrigation efficiency (A11), are even more preferred than the current alternatives that use the water supply of the São Francisco River transposition every month (A6). Once they have the capacity to reduce consumption, consequently less pressure on the demands on the reservoir.

Considering the water needs of the semi-arid region in which the Epitácio Pessoa Reservoir is located, the water insecurity conditions of the transposition water supply basin, and the diverse costs of the system, the alternatives that use water supply in the period of most minor influx due to precipitation are best evaluated together with management alternatives that adopt energy-saving equipment and consumption efficiency (A12 and A8).

\section{CONCLUSIONS}

The present study used a flow network model applied to a complex water system. Given the simulation of water demand management alternatives, it was necessary to use a decision tool that contemplated criteria and ranked the best alternative (s). Therefore, the flow network was associated with a multicriteria analysis method, the AHP-Entropy, as a hybrid approach.

Methodologically, such a hybrid approach made it possible to synthesize the results of the hydro system simulation, in view of the four pre-established criteria: meeting human demand; meeting the demand for irrigation; frequency of the reservoir volume below the target volume; and consumption reduction, summarizing the demand management alternatives in a ranking.

The flow network simulations represented both the historic water insecurity of the municipalities served by the Epitácio Pessoa Reservoir due to extreme droughts, such as the 2012-2017 drought, and the inefficiency in water-crisis management. Thus, from the ranking of the simulated alternatives, it was possible to indicate those that propose saving mechanisms and increase efficiency in water use. Therefore, these alternatives point out the need of approaches based on rationality, modernization and water management sustainability.

From the perspective of water demand management, it can be concluded that with the availability of data referring to the use of water, and physical and climatological characteristics of complex hydro systems, it is possible to apply a hybrid approach of flow network and AHPEntropy to simulate and classify the better alternatives for water demand management, which may support and simplify the decision-making process.

\section{ACKNOWLEDGMENT}

The authors acknowledge the financial support given by CAPES.

\section{REFERENCES}

ABOKIFA, A. A.; YANG, Y. J.; LO, C. S.; BISWAS, P. Water quality modeling in the dead end sections of drinking water distribution networks. Water research, v. 89, p. 107-117. 
2016. https://doi.org/10.1016/j.watres.2015.11.025

AL GARNI, H.; KASSEM, A.; AWASTHI, A.; KOMLJENOVIC, D.; AL-HADDAD, K. A. multicriteria decision making approach for evaluating renewable power generation sources in Saudi Arabia. Sustainable energy technologies and assessments, v. 16, p. 137-150, 2016. https://doi.org/10.1016/j.seta.2016.05.006

ALAMANOS, A.; MYLOPOULOS, N.; LOUKAS, A.; GAITANAROS, D. An integrated multicriteria analysis tool for evaluating water resource management strategies. Water, v. 10, n. 12, p. 1795, 2018. https://doi.org/10.3390/w10121795

ALMEIDA, M. A. D.; CURI, W. F. Gestão do uso de água na bacia do Rio Paraíba, PB, Brasil com base em modelos de outorga e cobrança. Revista Ambiente \& Água, v. 11, n. 4, p. 989-1005, 2016. https://doi.org/10.4136/ambi-agua.1820

ANA (Brasil). Pré-operação do eixo leste PISF: Sistema Hídrico Rio Paraíba-Açude Boqueirão. 03 out. 2017. Available at: https://www2.camara.leg.br/atividadelegislativa/comissoes/comissoes-permanentes/cindra/arquivos/sr-rodrigo-ana Access: 01 Apr. 2020.

ANDRADE, A. R.; LIMA, P. R. C.; OLIVEIRA, J. V. P.; LUCENA, D. B. Análise da relação entre precipitação e volume nas sub-bacias contribuintes para o açude Epitácio Pessoa. $\begin{array}{llllll}\text { Revista Brasileira de } & \text { Climatologia, } & \text { v. }\end{array}$ http://dx.doi.org/10.5380/abclima.v25i0.62973

ARAÚJO, M. D.; RIBEIRO, M. M. R.; BRAGA, C. F. C. Integrando a modelagem da alocação de água ao sistema de indicadores FPEIR: aplicação ao semiárido do Brasil. Engenharia Sanitária e Ambiental, v. 24, n. 6, p. 1167-1181, 2019. https://doi.org/10.1590/s141341522019184425

BAILONE, R. L.; ROÇA, R. O. Trends in processing broiler: rational use of water. Engenharia Sanitária e Ambiental, v. 22, n. 1, p. 65-72, 2017. http://dx.doi.org/10.1590/s141341522016154650

BAKHSHIANLAMOUKI, E.; MASIA, S.; KARIMI, P.; VAN DER ZAAG, P.; SUŠNIK, J. A system dynamics model to quantify the impacts of restoration measures on the waterenergy-food nexus in the Urmia Lake Basin, Iran. Science of the Total Environment, v. 708, p. 134874, 2020. https://doi.org/10.1016/j.scitotenv.2019.134874

BARROS, M. B.; RUFINO, I. A. A.; MIRANDA, L. I. B. Mecanismos poupadores de água como suporte ao planejamento urbano. Revista Brasileira de Recursos Hídricos, v. 21, n. 1, p. 251-262. 2016. http://dx.doi.org/10.21168/rbrh.v21n1.p251-262

BORAN, F. E. A new approach for evaluation of renewable energy resources: A case of Turkey. Energy Sources, Part B: Economics, Planning, and Policy, v. 13, n. 3, p. 196-204, 2018. https://doi.org/10.1080/15567249.2017.1423414

BOULOS, P. F. Smart water network modeling for sustainable and resilient infrastructure. Water Resources Management, v. 31, n. 10, p. 3177-3188, 2017. https://doi.org/10.1007/s11269-017-1699-1

DING, Z.; ZHU, M.; WU, Z.; FU, Y.; LIU, X. Combining AHP-entropy approach with GIS for 
construction waste landfill selection-A case study of Shenzhen. International journal of environmental research and public health, v. 15, n. 10, p. 2254, 2018. https://doi.org/10.3390/ijerph15102254

FEIZI, F.; KARBALAEI-RAMEZANALI, A.; TUSI, H. Mineral potential mapping via TOPSIS with hybrid AHP-Shannon entropy weighting of evidence: a case study for porphyry-cu, Farmahin area, Markazi Province, Iran. Natural Resources Research, v. 26, n. 4, p. 553-570, 2017. https://doi.org/10.1007/s11053-017-9338-3

LEAL, J. E. AHP-express: A simplified version of the analytical hierarchy process method. MethodsX, v. 7, p. 100748, 2020. https://doi.org/10.1016/j.mex.2019.11.021

LOTFI, F. H.; FALLAHNEJAD, R. Imprecise Shannon's entropy and multi-attribute decision making. Entropy, v. 12, n. 1, p. 53-62, 2010. https://doi.org/10.3390/e12010053

MULLINER, E.; MALYS, N.; MALIENE, V. Comparative analysis of MCDM methods for the assessment of sustainable housing affordability. Omega, v. 59, p. 146-156, 2016. https://doi.org/10.1016/j.omega.2015.05.013

RÊGO, J. C.; GALVÃO, C. O.; ALBUQUERQUE, J. P. T.; RIBEIRO, M. M. R.; NUNES, T. H. C. A Gestão de Recursos Hídricos e a Transposição de Águas do Rio São Francisco para o Açude Epitácio Pessoa-Boqueirão. In: SIMPÓSIO BRASILEIRO DE RECURSOS HÍDRICOS, 22., 2017, Florianópolis. Proceedings[...] Florianópolis: ABRH, 2017. 1 CD-ROM.

ROODPOSHTI, S. M.; ARYAL, J.; SHAHABI, H.; SAFARRAD, T. Fuzzy Shannon entropy: A hybrid gis-based landslide susceptibility mapping method. Entropy, v. 18, n. 10, p. 343, 2016. https://doi.org/10.3390/e18100343

SAATY, T. L. Response to Holder's comments on the analytic hierarchy process. Journal of the Operational Research Society, v. 42, n. 10, p. 909-914, 1991. https://doi.org/10.1057/jors.1991.176

SANTOS, A. R. D.; SILVA, R. C. F. D.; ASSIS, L. C. D.; MAUAD, F. F. Defining environmental conservation levels considering anthropic activity in the Uberaba River Basin protected area. Revista Ambiente \& Água, v. 14, n. 1, p. 20-33, 2019. https://doi.org/10.4136/ambi-agua.2279

SHABBIR, R.; AHMAD, S. S. Water resource vulnerability assessment in Rawalpindi and Islamabad, Pakistan using analytic hierarchy process (AHP). Journal of King Saud $\begin{array}{lllllll}\text { University-Science, } & \text { v. } 28, \quad \text { n. } & 4, & \text { p. } & \text { 293-299, } 2016 .\end{array}$ https://doi.org/10.1016/j.jksus.2015.09.007

SHANNON, C. E. Prediction and entropy of printed English. Bell system technical journal, v. 30, n. 1, p. 50-64, 1951. https://doi.org/10.1002/j.1538-7305.1951.tb01366.x

SHOURIAN, M.; RAOUFI, Y.; ATTARI, J. Interbasin water transfer capacity design by two approaches of simulation-optimization and multicriteria decision making. Journal of Water Resources Planning and Management, v. 143, n. 9, p. 04017054, 2017.

SILVA, S. M. O.; SOUZA FILHO, F. D. A.; CID, D. A. C.; AQUINO, S. H. S. D.; XAVIER, L. C. P. Proposta de gestão integrada das águas urbanas como estratégia de promoção da segurança hídrica: o caso de Fortaleza. Engenharia Sanitária e Ambiental, v. 24, n. 2, 
p. 239-250, 2019. https://doi.org/10.1590/s1413-41522019181776

SOUSA, L. C. O. Gestão da demanda de água no Agreste pernambucano. 2017. 88f. (Dissertação de Mestrado) - Universidade Federal de Pernambuco, Caruaru, 2017.

ŠTREIMIKIENĖ, D.; ŠLIOGERIENĖ, J.; TURSKIS, Z. Multi-criteria analysis of electricity generation technologies in Lithuania. Renewable energy, v. 85, p. 148-156, 2016. https://doi.org/10.1016/j.renene.2015.06.032

TSCHEIKNER-GRATL, F.; EGGER, P.; RAUCH, W.; KLEIDORFER, M. Comparison of multi-criteria decision support methods for integrated rehabilitation prioritization. Water, v. 9, n. 2, p. 68, 2017. https://doi.org/10.3390/w9020068

VIEIRA, A. S.; CURI, W. F. Evidenciação dos modelos de simulação e técnicas para o planejamento integrado dos sistemas hídricos. Revista Gestão \& Sustentabilidade Ambiental, v. 5, n. 1, p. 233-266, 2016. http://dx.doi.org/10.19177/rgsa.v5e12016233266

VIEIRA, J. A. M.; GOMES, C. F. S.; BRAGA, I. E. Development of a scenario prospecting model with the use of multicriteria decision aiding: Importance of environmental variables. Brazilian Journal of Operations \& Production Management, v. 14, n. 2, p. 210-217, 2017. https://doi.org/10.14488/BJOPM.2017.v14.n2.a9

YANG, Y.; YUAN, G.; ZHUANG, Q.; TIAN, G. Multi-objective low-carbon disassembly line balancing for agricultural machinery using MDFOA and fuzzy AHP. Journal of Cleaner Production, v. 233, p. 1465-1474, 2019. https://doi.org/10.1016/j.jclepro.2019.06.035 